\title{
Research of Enterprise Information Resources Management System and Strategy Evaluation
}

\author{
Wenzhou ZHANG \\ Hubei University of Arts and Science \\ Xiangyang Hubei, 441053, China
}

\begin{abstract}
In the face of economic globalization and increasing competition trends, how to accelerate the application of information resource management in the enterprise, the information resources management level of our business can be greatly improved and we can promote business by leaps and bounds, and we can enhance its competitiveness in the international market. It has become China's enterprises' severe problems. This paper describes the status of information resource management of Chinese enterprises, enterprise information resources management problems in the process and the necessity of building up information resources management analysis, and the Construction of Enterprise Information Resource Management System makes us put forward some policy recommendations.
\end{abstract}

Keywords- Information; resource management; Build

\section{INTRODUCTION}

Information Resources Management is dedicated for a specific term, in the 1970s, first appeared in the United States. It is currently a hot area of the worldwide development and utilization of information. Information resource management refers to information resources, including information, information technology, information systems and information management personnel and others. Information resources management puts much emphasis on information, information technology and information management personnel and other composite of integrated multi-factor, emphasizing the information goods and information equipment, focusing on the application of information in the field of economic theory, highlighting the management of information resources from an economic perspective. With the development of information technology, more and more companies are starting to focus on information resources management, research on this aspect of domestic scholars have made great results.

\section{ANALYSIS OF THE PROBLEM OF INFORMATION RESOURCES MANAGEMENT EXISTED IN THE OIL ENTERPRISES}

\section{A. Information Resources Management Reform efforts need to be strengthened}

In recent years, with the rapid development of the global science and technology, in order to achieve greater success,
China's enterprises must comply with the new trend of the current global economic development, namely to take reasonable information technology and information resources management strategy to reform the traditional management and operating modes. However, at this stage, some companies fear the cost of information technology as well as the staff of the new mode of acceptance problems and many other factors. They are hesitant and do not attach importance to the development of enterprise information resources management strategy, enterprise information resources management and thus it caused great obstacles. This paper argues that our business managers and employees must fully recognize the importance of enterprise information resources management, from the psychological and practical action up to promoting enterprise information resources management.

\section{B. Information Resources Management Construction Is Difficult}

Industry chain is long, from the production, transportation, processing and marketing, finally to the end customer, which involves a number of aspects. Multiindustry association of enterprises, business units widely distributed. Large-scale enterprises make the management structure of the industry's complex, management points decentralized. This requires that enterprises have a master plan in the information technology. For years, due to lack of co-ordination arrangements in information technology, each large enterprise fragmentation, duplication, standards are not uniform, the low level of information, is not only a waste of resources caused by information, but also has brought great difficulties to the entire industry information optimization, upgrade and expansion in making the construction of information resource management more difficult.

\section{Lack of Relative Research}

At present, China's enterprise managers have come to realize management and information resource management system for its importance of information resources management. Innovation and building management systems is related to the needs of our corporate management model to study the application of information technology as the foundation. However, China's enterprises relatively invest less to research in this area. There is a total investment of $1 \%$ to $2 \%$ of total sales of large foreign construction company information for businesses in general, while the vast majority of enterprises in the information resource management inputs fall far short of this standard. In recent years, some Chinese 
companies have generally increased resource aspects of information technology research funding. However, in terms of production scale compared to these changes in the proportion of investment companies in the information technology innovation, it is relatively small, and, as a result of the high cost of information resource management constraints, the construction of enterprise information resources management process still has no shortage of funds phenomenon To some extent, it hinders the development of enterprise information resources management processes.

\section{THE STRUCTURE AND CONTENT OF INFORMATION RESOURCES MANAGEMENT DISCIPLINE SYSTEM}

Given the diverse perspectives of information resources management research, we can build the basic framework of information resources management discipline system from three dimensions:

According to the object classification information resource management, information resource management can be divided into basic sciences, business information resource management disciplines, government information resource management disciplines, LIS archival information resources management discipline, special areas of information resource management discipline, discipline and other network information resources management . Information resource management infrastructure disciplines include basic theory disciplines, methods disciplines, history of science. Basic theoretical disciplines also include information resource management theory, knowledge management theory, organizational management theory, information economics, information resource policies and other regulations; method of disciplines include information organization and retrieval, information consulting, information analysis, information systems analysis and design. History of disciplines include the history of Western thought information resource management, history and other information resources management; database technology, data mining, information security technology, information storage technology, metadata, and so on. Enterprise Information Resource Management disciplines also include knowledge management, management information systems, enterprise website construction, e-commerce, enterprise resource planning (ERP) technology, customer relationship management (CRM) technology, supply chain management (SCM) technology, CIOs (CIO), enterprise information resources safety, competitive intelligence. Government information resources management disciplines include public administration, information resources management plan, the government website construction, e-government, government information security management. LIS file information resources management disciplines include Library and Information Resource Management, Information Center, Information Resources Management and Archives department of information resources management. Special areas of information resource management disciplines include some of the more segments in the field of human resources management information, military information resource management.
According to information resources management process, information resource management disciplines can be divided into information resource demand analysis disciplines, disciplines gathering information resources and information resources to deal with discipline, information resources stored disciplines, information resources and information resources management disciplines Subjects. Information Resources disciplines include information retrieval, information consulting, information analysis, information services, information resources policies and regulations, information security management. Information Resources Management Subjects include information resource management on the basis of theory and process integration of relevant content, specifically information resource management theory, knowledge management theory, organizational management theory, information economics, e-government, e-commerce, government websites, corporate websites competitive intelligence. Information resources are all the information as symbols stored in a certain carrier (including the brain) that can be used on after human's series of awareness and thinking of the creative process. Information, people, symbols, and the carrier is the most basic of information resources four kinds of components. Through understanding of these four elements of the "people", it can be concluded that the information into a resource is a personal thing, so the personalized features of information resources is obvious. This requires managers to fully understand the role of people, improve management and improve employee information into the ability to expand their own information resources reserves. Meanwhile, the four elements of information and symbols of these two elements is not a one to one relationship of understanding, then the information resource demands on the carrier is not static. When changing information into work in the enterprise, we should pay attention to proper selection of the information carrier, the information encoded science, and to ask the staff for all levels of the enterprise information (knowledge) the depth of excavation. To sum up, the enterprise information resources management has the following seven characteristics: It is a basic principle of the system of science and science-based management of the new resource management; its services are mainly to collect dynamic information and organize, conduct in-depth knowledge of mining, according to the requirements of timely, accurate and meet the needs of users through the use of advanced information technology; it is a comprehensive management strategy in order to achieve business objectives of information resources, rather than purely technical management; it emphasizes strategic information resources and senior management, not just in the operating level, executive level management, and the establishment of the power structure of information resources management from the level of strategic planning and decision-making; it is business-oriented institution, its organization and management must match the business organization, for the overall strategic objectives of the service organization; it is an important task at all levels of the organization of various functional managers, and not just the responsibility of the officer is in charge of information resources; it emphasizes 
the integration of all information resources integration, unified configuration and system management, the pursuit of global optimal allocation of resources, rather than local optimization of individual components of the resource. Through the Enterprise Information Resource Management feature summary, it can be seen that enterprise information resources management is a management approach. It is a global, dynamic, systematic management process; its management objectives should serve as a business development goals; although it emphasized the support of senior management and the need to be included in all incoming corporate officers at all levels of the respective responsibilities. This will give us the resources to optimize enterprise information management to provide useful inspiration.

\section{REVELATION OF ENTERPRISE INFORMATION RESOURCES MANAGEMENT ELEMENTS AND FEATURES}

\section{A. Information Process Backward}

Because corporate information resources have timely, practical, professional, value-added features and sharing, we can only accurate information processing analysis in order to obtain useful information for business decisions. However, ways and means of enterprise information processing is still relatively backward, and information requirements far from satisfactory. According to statistics, among China's existing 16,000 large enterprises, only about $10 \%$ complete the information network framework. Among 10 million SMEs, only $5 \%$ have some means of information. Lag of information processing means became restriction of enterprise information "bottleneck".

\section{B. Information Resources Management System Absence}

Survey shows that in our country a considerable number of enterprise information resources management is often part-time work by the staff of other departments. Even when a person is responsible for information resource management companies, responsible for information resource management, information technology personnel take part in less than half of the corporate decision-making. Many companies never even do consolidation and cleanup of information on the enterprise reserves, development, integration and utilization. If the information cannot be business as a strategic resource, then the business information is difficult to play a role in corporate decisionmaking and development.

\section{Professional Quality Information Resources Management Needs To Be Improved}

Professional manager of information resources needs not only information resources management theoretical knowledge, but also understanding of computer technology and to be well versed in business management operations. Information Resource Management Knowledge structure of stage business is not perfect, the quality has to be improved, which restricts the quality and efficiency of enterprise information resources management largely.

There are many error-prone in the process of enterprise information resources management. For example, many enterprises, especially SMEs, the Information Resources Management Service object location for corporate executives and decision-makers, and the general staff are of the exclusion, which resulted in internal information asymmetry, but also hindering the information resources transformation. Meanwhile, in the pursuit of short-term effects, many companies focus on internal information collection, the expense of the vast and complex information gathering outside the enterprise, this will lead to a lack of corporate external competitive. In addition, the mistake company often make is that they only pay attention to collecting and accumulating information, ignoring the information process and use. For example, digital information is not standardized, update information is not in time, resulting in a lack of basic information resources. This makes that the information resources management stays in a very low stage and hinders the development of enterprises.

\section{CONCLUSIONS}

Information process, particularly computer technology, advances. The development of all walks of life plays a huge role in promoting. Application of information technology improves the management capacity of Chinese enterprises, operating performance and R \& D capability has a vital role. The process of enterprise information directly determines the degree of its production capacity and core competitiveness. In order to improve the core competitiveness of enterprises as soon as possible, transforming the mode of economic development and strengthening the enterprise's information resources management process is very necessary.

\section{References}

[1] Qi Lili. Study of Information Resource Management System of Value-driven Manufacturing Enterprise [D]. Hebei University of Technology, 2002.

[2] Liu Lingbing. Enterprise Information Resource Accounting Reporting Research [D]. Dongbei University of Finance and Economics, 2012.

[3] Hu Qian. Information Services Industry Reorganization Research For Innovation and Development of Enterprises [D]. Wuhan University, 2009.

[4] Wei Dongdong. Innovative Enterprise Information Security Research [D]. Anhui University, 2013.

[5] Chang Liang. Enterprise Information Resources Security Management System Construction [D]. Jilin University, 2009.

[6] Xu Qianqian. Manufacturing Enterprises Management Information Resource Evaluation Based On Supply Chain [D]. Beijing Jiaotong University, 2009.

[7] Chang Yunyue. Our Multinational Enterprise Information System Construction Research [D]. East China Normal University, 2007. 